\title{
THE ROLE OF NATIONAL ECONOMY IN THE FORMATION OF NATIONAL RESETTLEMENT SYSTEM
}

\author{
Anatoliy DOTSENKO \\ Open International University of Human Development "Ukraine", Kyiv, Ukraine
}

\begin{abstract}
The article describes the influence of the national economy, being one of the most important economic factors, on the formation of a national resettlement system on the example of Ukraine at the beginning of XXI century, addressing the general and special features of the national economy, especially its development and structure. The author analyses basic theoretical issues related to the influence of national economy transformation on the development of the national resettlement system in Ukraine.

Key words: system, resettlement, settlement, transformation, market, structure.
\end{abstract}

UDC: 911.37

\section{РОЛЬ НАЦІОНАЛЬНОÏ ЕКОНОМІКИ У ФОРМУВАННІ НАЦІОНАЛЬНОЇ СИСТЕМИ РОЗСЕЛЕННЯ}

\author{
Анатолій ДОЦЕНКО \\ Відкритий міжнародний університет розвитку людини «Україна», м. Київ, Україна
}

\begin{abstract}
Анотація: У статті розглянуто вплив одного із найважливіших економічних чинників - національної економіки - на формування національної системи розселення на прикладі України на початку XXI ст. Розкрито загальні та особливі ознаки національної економіки, особливості її розвитку та структури. Розглянуті основні теоретичні питання впливу трансформації національної економіки на розвиток національної системи розселення населення України.
\end{abstract}

Ключові слова: система, розселення, поселення, трансформація, ринок, структура.

Удк: 911.37

Вступ. Постановка проблеми. Розселення - складний суспільно-географічний процес, який розвивається під впливом багатьох чинників, з них визначальним $\epsilon$ економічний. Вплив економічних чинників на формування і структуру територіальних систем розселення складний i багатогранний. Географи приділяли найбільшу увагу дослідженню регіональних систем розселення. Проте теоретикометодологічні засади формування систем розселення на національному рівні розроблені слабо, що зумовлено недостатньою увагою українських вчених до цієї важливої проблеми. Серед чинників формування в Україні національної системи розселення визначальну роль відіграє процес становлення національної економіки на базі реформованої на ринкових засадах радянської економіки. Отже, ця тема в сучасний період набула актуального значення.

Аналіз останніх досліджень і публікацій. Концепція національної системи розселення вперше була висунута нами у 2004 році. Проаналізувавши динаміку розселення в Україні в кінці ХХ ст., ми зробили висновок: «В результаті взаємопов'язаного та взаємозалежного розвитку міських та сільських поселень в Україні об'єктивно формується національна система розселення, екологічною базою якої $\epsilon$ національний територіально-господарський комплекс» [5, с. 97]. Пізніше ця концепція була сформульована нами більш чітко [2, с. 147]. Формування національної системи розселення

(C) А. Доценко розглядалося нами як один із стратегічних напрямків удосконалення територіально-системної організації розселення населення [1, с. 281-288].

Важливе наукове значення мають визначені економістами Т.А.Заяць, Т.Г.Кравцовою і В. Л. Танцюрою головні ознаки, принципи, тенденції та чинники розвитку національної системи розселення. Авторами розроблена стратегічна мета та цільові завдання концепції розвитку національної системи розселення, а також заходи щодо ii оптимізації [6, с. 152-158].

Серед новітніх публікацій із досліджуваної теми слід відзначити видану у 2013 році монографію Л. Б. Заставецької, в якій значна увага приділена теоретико-методологічним засадам суспільногеографічного дослідження територіальних систем розселення. Визначаючи найвищим таксономічним рівнем ієрархічної класифікації систем розселення загальнодержавну систему, або «систему розселення країни», сформовану на національному рівні, автор досліджувала системи розселення лише регіонального та локального рівня [7, с. 27].

Вищевизначене зумовлює необхідність спеціального дослідження національної системи розселення, зокрема аналізу впливу чинників на ii формування.

Формування цілей, постановка завдання. Метою написання статті $є$ суспільно-географічний аналіз впливу національної економіки на формування і структуру національної системи розселення населення України. Для досягнення цієї мети 
передбачено виконання деяких завдань.

Виклад основного матеріалу. Національна система розселення $€$ закономірним етапом i важливою формою територіальної організації розселення. Формування національної системи розселення - це складний, об'єктивний і тривалий процес, який відбувається поступово на певних етапах економічного та соціального розвитку країни. Серед багатьох чинників, що впливають на формування національної системи розселення, вирішальними $є$ економічні. Причому в сучасний період в умовах становлення та функціонування ринкової економіки в Україні вплив економічних чинників принципово відрізняється від радянської соціалістичної планової економіки. В результаті цього відбулася кардинальна зміна економічної бази функціонування національної і територіальних систем розселення. Слід зазначити, що це не призвело до ліквідації старих та виникнення нових систем розселення. В кінці XX - на початку XXI ст. відбулася трансформація загальнодержавної системи розселення у якісно нову національну систему та територіальних систем розселення, що відбулася під впливом економічних чинників. Серед останніх значної уваги географів потребує вивчення процесу функціонування національної економіки та її впливу на національну систему розселення. Для цього спочатку необхідно з'ясувати сутність національної економіки та особливості їі структури.

«Національна економіка, 3 одного боку - це господарський комплекс певної країни, а 3 іншого боку, це вчення про закономірності становлення та функціонування господарської системи суспільства» [3, с. 7]. 3 позицій системного підходу національна економіка являє собою економічну систему 3 інтенсивними внутрішньодержавними міжрегіональними соціально-економічними зв'язками, що забезпечують економічну єдність країни та взаємопов'язаність регіонів.

За 24 роки незалежності України відбувся складний і тривалий процес трансформації радянської планової економіки у принципово нову економічну систему - національну економіку, що сформувалася на базі ринкової економіки. В результаті розширення ринкових економічних відносин посилилися міжрегіональні економічні зв'язки, що сприяло економічній єдності України. Не менш важливо зазначити, що відбулося поглиблення територіального поділу праці між регіонами України та певні зміни спеціалізації їх господарства, що зумовило відповідні зрушення товарної структури економічних зв'язків як на національному, так i міжнародному рівнях. В свою чергу це знайшло певний відбиток на національній системі розселення, зокрема кількісних та якісних змінах внутрішньодержавних міжрегіональних зв'язків.

Розглядаючи національну економіку як систему ми знаходимо тісні взаємозв'язки їі з національною системою розселення, що прослідковуються у двох аспектах: економічному та соціальному.

Зміцнення економічних зв'язків між національною системою розселення i національною еко- номікою зумовлено, 3 одного боку, збільшенням економічного потенціалу країни, а 3 іншого, динамічністю міжрегіональних зв'язків в умовах постійних змін економічної кон'юнктури. Про зміцнення економічного потенціалу України свідчить значне збільшення валового внутрішнього продукту, у 2013 р. порівняно з 2000 р. у 8,9 рази. Це пов'язане частково за рахунок підвищення інфляції, але головним чином в результаті модернізації існуючих та будівництва нових виробництв та обслуговуючих закладів.

Соціальні зв'язки національної економіки 3 національною системою розселення здійснюються у декількох напрямах. Перш за все, це забезпечення потреби підприємств у кадрах різних професій та рівнів кваліфікації. За 20 років вимоги українських працедавців до кількості та якості кадрів докорінно змінилися. В результаті масового закриття промислових підприємств та зростання безробіття різко зменшився обсяг міграції працездатного населення, у тому числі й «маятникової» між місцями розселення та прикладання праці. Істотні зміни відбулися в структурі міграційних потоків. При значному зменшенні кількості вакантних місць працедавці підвищили вимоги до якості кадрового персоналу. На ринку праці мають попит лише деякі традиційні професії, а також нові, зумовлені науково-технічною революцією та модернізацією виробництва.

Не менш важливі соціальні зв'язки між розселенням та економікою, зумовлені курсом держави на побудову соціально-орієнтованої економіки. В сучасний період в Україні спостерігається процес соціалізації національної економіки, пов'язаний 3 розвитком гуманітарних, соціальних та суспільних процесів, які у взаємозв'язку становлять соціальний вектор економічного розвитку. Вплив соціальної складової на розвиток економіки України проявляється у прискоренні розвитку іiі соціальної та ринкової інфраструктури, а також у збільшенні частки доходів від соціальної сфери в структурі ВВП країни. Отже, в сучасний період відбувається активізація соціальних зв'язків між національною економікою та національною системою розселення, у межах якої зміцнюється соціальна інфраструктура. Для досягнення ефективності національної економіки необхідно забезпечити збалансованість, з одного боку, між соціальною, інженерною та виробничою інфраструктурою, $з$ другого, між виробництвом та інфраструктурою, а 3 третього, між економікою та розселенням.

Національна економіка України знаходиться в процесі безперервного розвитку та трансформації, що зумовлює певні зміни іiі структури. Все це відповідно змінило вплив економічних чинників на розселення, зокрема на функціонування національної системи розселення. Вчені виділяють чотири етапи становлення національної економіки України, 3 яких останній (2001-2015рр.) характеризується становленням ринкових механізмів функціонування національної економіки. Нові умови господарювання істотно змінили взаємовідносини між економікою та 
розселенням. Національний ринок разом з державою став відігравати роль головного регулятора розвитку і структури національної економіки. В процесі ринкової трансформації економіка України поступово набуває ознак, притаманних економічно розвиненим європейським країнам. Реалізація курсу на євроінтеграцію вимагає проведення радикальних економічних реформ, впровадження новітніх технологій, модернізацію виробництва, пріоритетного розвитку інноваційної економіки, залучення величезних інвестицій.

Все це зумовить істотні зміни стратегії розвитку національної системи розселення. Реалізація нової Стратегії сталого розвитку «Україна - 2020», затвердженої 12 січня 2015 р., створить принципово нові умови для розвитку міст, особливо великих. Пріоритетного розвитку набудуть міста-центри регіональних та субрегіональних систем розселення.

Перспективи розвитку середніх міст залежатимуть від місця їх у національній системі територіального поділу праці та національній системі розселення. Стратегічні напрями розвитку малих міст, селищ та сіл будуть пов'язані з реформуванням адміністративно-територіального устрою України, децентралізацією влади та укрупненням територіальних громад.

Істотні зміни економічних зв'язків у національній системі розселення пов'язані також iз функціонуванням багатоукладної економіки України, в якій поєднуються сектори різних форм власності. В результаті роздержавлення економіки, формування галузей та видів економічної діяльності, що грунтуються на приватній власності, істотно змінилася потужність, географія та структура економічних зв'язків у межах національної системи розселення. Визначальними критеріями цих зв'язків стали не доступність і територіальна близькість, а прибутковість економічної діяльності, висока якість та конкурентоспроможність продукції. Розселенрський чинник, в одних умовах, може сприяти досягненню цих критеріїв, а в інших - гальмувати.

За роки незалежності України відбулися принципові зміни структури національної економіки, яка за міжнародною класифікацією видів економічної діяльності характеризується певними змінами. За даними Державної служби статистики України, за останні 13 років (2001 - 2013 рр.) найбільший приріст ВВП спостерігався у постачанні електроенергії, газу та води (на 47,5\%),а також у сільському та лісовому господарстві (38,5\%).В той же час найменший приріст ВВП мали добувна (20,2\%) та обробна промисловість (27,6\%). В результаті цього, відбулися деякі зміни в структурі національної економіки, пов'язані зі значним зниженням питомої ваги обробної промисловості ( 3 44,4\% у 2000 р. до 41,5\% у 2013 р.) та підвищенням торгівлі та ремонту автотранспортних засобів (з 16\% до $17 \%$ ) а також сільського та лісового господарства (з 10,7 \% до 11,5 \%). Ці зрушення відповідно зумовили зміни потужності та географії економічних зв'язків у національній та регіональних системах розселення. Зазначені тенденції збережуться і в перспективі до 2020 року.

Висновки. Отже, формування національної системи розселення є об'єктивним i тривалим процесом, економічною базою якого є становлення національної економіки. Національній економіці України притаманні як загальні, так і особливі ознаки, що зумовлюють особливості впливу १ii на національну систему розселення. Деякі теоретичні питання цього впливу розглянуті у статті.

\section{References:}

1. Docenko A. Ì. Teritorial'na organizaciâ rozselennâ (teoriâ ta praktika) [Territorial organization of settlement (theory and practice)]. Kyiv, 2010, 536 p.

2. Docenko A. Ì., Zìnič V. T., Velikohat'ko O. T., Tancûra V. L. Rozselennâ v Ukraïnì: problemi ì perspektivi [Settlement in Ukraine: problems and prospects]. Kyiv, 2006, 269 p.

3. Nacional'na ekonomika. Navčal'nij posibnik [National economy. Textbook]. Ed. Savčenko A. G. Kyiv, 2011, $646 \mathrm{p}$.

4. Statističnij Ŝričnik Ukrä̈ni za 2013 rik [Statistical Yearbook of Ukraine (2013)]. Kyiv, 2014, 533 p.

5. Strategični naprâmi ta perspektivi rozvitku produktivnih sil Ukraïni [Strategic directions and prospects of productive forces development in Ukraine]. Kyiv, 2004, $130 \mathrm{c}$.

6. Zaâc' T. A., Kravcova T. G., Tancûra V. L. Konceptual'nì osnovi rozvitku nacìonal'noï sistemi rozselennâ [Conceptual bases of national settlement system development]. Produktivnì sili Ukraïni [Productive forces of Ukraine], 2008, Vol. 1.

7. Zastavec'ka L. B. Sistemi rozselennâ ì geoprostorovi problemi vdoskonalennâ admìnistrativno-teritorial'nogo ustroû Ukraïni [Settlement system and geospatial problems of improvement of administrative-territorial division of Ukraine]. Ternopil, 2013, 332 p. 